\title{
Human Disturbances of Denning Polar Bears in Alaska
}

\author{
STEVEN C. AMSTRUP 1,2
}

(Received 27 August 1992; accepted in revised form 15 April 1993)

\begin{abstract}
Polar bears (Ursus maritimus) give birth in dens of snow and ice. The altricial neonates cannot leave the den for $>2$ months post-partum and are potentially vulnerable to disturbances near dens. The coastal plain (1002) area of Alaska's Arctic National Wildlife Refuge (ANWR) lies in a region of known polar bear denning and also may contain $>9$ billion barrels of recoverable oil. Polar bears in dens could be affected in many ways by hydrocarbon development, but neither the distribution of dens nor the sensitivity of bears in dens has been known. I documented the distribution of dens on ANWR between 1981 and 1992 and observed responses of bears in dens to various anthropogenic disturbances. Of 44 dens located by radiotelemetry on the mainland coast of Alaska and Canada, 20 (45\%) were on ANWR and $15(34 \%)$ were within the 1002 area. Thus, development of ANWR will increase the potential that denning polar bears are disturbed by human activities. However, perturbations resulting from capture, marking, and radiotracking maternal bears did not affect litter sizes or stature of cubs produced. Likewise, 10 of 12 denned polar bears tolerated exposure to exceptional levels of activity. This tolerance and the fact that investment in the denning effort increases through the winter indicated that spatial and temporal restrictions on developments could prevent the potential for many disruptions of denned bears from being realized.
\end{abstract}

Key words: Alaska, ANWR, Arctic, denning, disturbance, impact, oil development, polar bear, reproduction, Ursus maritimus

RÉSUMÉ. Les ourses polaires (Ursus maritimus) donnent naissance à leurs petits dans des tanières de neige et de glace. Les nouveau-nés nidicoles ne peuvent quitter la tanière avant au moins deux mois suivant leur naissance, et des perturbations près de leur tanière sont susceptibles de les affecter. La région de la plaine côtière (1002) du Arctic National Wildlife Refuge (ANWR) en Alaska est située dans une zone connue comme site de mise bas pour l'ourse polaire et qui pourrait contenir plus de neuf milliards de barils de pétrole récupérable. Les ours polaires dans les tanières pourraient être affectés de bien des façons par l'exploitation des hydrocarbures, mais on n'a pas de données que ce soit sur la distribution des tanières ou sur la sensibilité des ours à l'intérieur de celles-ci. Nous avons documenté la distribution des tanières dans l'ANWR entre 1981 et 1992 , et y avons observé la réponse des ours à diverses perturbations anthropiques. Parmi les 44 tanières localisées par radio-télémétrie sur la côte continentale de l'Alaska et du Canada, 20 (soit 45 p. cent) étaient situées dans l'ANWR et 15 (soit $34 \mathrm{p}$. cent) l'étaient dans la zone 1002. La mise en valeur de l'ANWR va donc accroître le potentiel de perturbation des ours polaires par l'activité humaine. Les perturbations résultant de la capture, du marquage et du pistage radio-électrique des mères ourses n'ont cependant pas affecté le nombre de petits dans une portée ni la taille des oursons. En outre, de 10 à 12 des ours polaires vivant dans leur tanière supportaient l'exposition à un niveau d'activité relativement intense. Cette tolérance et le fait que l'investissement dans la vie en tanière augmente au cours de l'hiver indiquent que des restrictions spatiales et temporelles imposées sur la mise en valeur pourraient empêcher que les ours en tanière soient soumis à d'éventuelles perturbations.

Mots clés : Alaska, ANWR, Arctique, mise bas dans les tanières, perturbation, impact, exploitation pétrolière, ours polaire, reproduction, Ursus maritimus

Traduit pour le journal par Nésida Loyer.

\section{INTRODUCTION}

Pregnant polar bears excavate dens of snow and ice in early winter (Harington, 1968; Lentfer and Hensel, 1980; Ramsay and Stirling, 1990) and give birth in December or early January (Kostyan, 1954; Harington, 1968; Ramsay and Dunbrack, 1986). The altricial neonates need to remain in the protective den for $>2$ months post-partum and therefore are potentially vulnerable to disturbances near dens. Section 1002 of the Alaska National Interest Lands Conservation Act (ANILCA) set aside 600000 ha of the coastal plain of the Arctic National Wildlife Refuge (ANWR) in northeastern Alaska for special study. This "1002" area may contain $>9$ billion barrels of recoverable oil and may be the most promising onshore oil and gas exploration area in the United States (Clough et al., 1987). Lentfer and Hensel (1980) and Amstrup et al. (1986) suggested many ways bears in dens might be impacted by hydrocarbon-related activities, and Amstrup and Gardner (1994) reported that polar bears denned most commonly along the northeastern coast of Alaska. Despite speculation, however, neither the distribution of dens on ANWR nor the sensitivity of bears to disturbances near their dens has been known.
This paper documents the use of ANWR for denning by polar bears between 1981 and 1992. Also, it summarizes information on responses of polar bears in dens to aircraft, over-snow vehicles, and foot traffic.

\section{METHODS}

Dens of female polar bears were located by satellite telemetry, very high frequency (VHF) aircraft telemetry, and aerial sightings of opened dens in fall and spring (Amstrup and Gardner, 1994). The nature and frequency of exposures of bears at den sites to human activities were recorded, and notes were kept on responses by bears and the subsequent outcome of the denning event. Responses of unmarked bears to various human activities were recorded opportunistically. These observations were few, but some disturbances caused by researchers were similar to those that might accompany industrial development and other endeavors. Therefore, responses of denned polar bears to research activities also were recorded.

The ultimate measure of den site disturbances is reproductive output. Therefore, I compared numbers (determined by observation, capture, or counting footprints in the snow),

\footnotetext{
'Alaska Fish and Wildlife Research Center, U.S. Fish and Wildlife Service, 1011 E. Tudor Road, Anchorage, Alaska 99503, U.S.A. ${ }^{2}$ Work completed in partial fulfillment of the requirements for a doctoral degree from the Department of Biology and Wildlife, University of Alaska Fairbanks, Fairbanks, Alaska 99775, U.S.A.

(C) The Arctic Institute of North America
} 
weights, and skull measurements (the sum of condylobasal length and zygomatic width) of cubs produced by radiocollared, marked, and new females captured after leaving dens. New females were subjected to no human disturbances prior to their capture upon emergence from the den in early spring. Marked and radiocollared females were exposed to one or more capture by helicopter darting (Amstrup and Gardner, 1994) prior to denning and subsequent recapture in the spring with new cubs. Radiocollared females were exposed while in dens to several overhead passes and circles with helicopters or fixed-wing aircraft in order to pinpoint their locations. Flights were conducted at altitudes of $150-500 \mathrm{~m}$ (unless otherwise stated), depending on weather conditions and topography. Activity levels of denned bears were determined during aerial monitoring by fluctuations in rate and strength of pulsed transmissions. Once den sites were accurately known, continued occupation of dens of radiocollared females was confirmed with more distant flights or activity and temperature data recorded by satellite radiocollars (Amstrup and Gardner, 1994).

Litter sizes of cubs produced by new, marked, and radiocollared females were compared with chi-squared contingency tables, and measurements of cubs were compared with the chi-squared approximation of the Kruskal-Wallis (KW) test (Conover, 1980). Statistical analyses were performed on a Data General AVIION 6200 computer (Data General Corp., Westboro, MA) running SAS version 6.07 software (SAS Institute, Inc., Cary, NC).

\section{RESULTS}

\section{Den Locations}

Using radiotelemetry between 1981 and 1992, I located 44 dens on land or land-fast ice along the mainland coast of Alaska and Canada. Of those, $20(45 \%)$ were within the bounds of ANWR, and 15 (34\%) were within the bounds of the 1002 area (Fig. 1). The ANWR and 1002 coasts constitute only $13 \%$ and $10 \%$ of the longitudinal range over which mainland dens were observed. In addition to the 20 dens within ANWR, 1 was on lands controlled by the village of Kaktovik and surrounded by ANWR lands, and 2 others were just offshore of the 1002 area on land-fast ice. Numerous dens also were found in Canada just east of ANWR (Fig. 1).

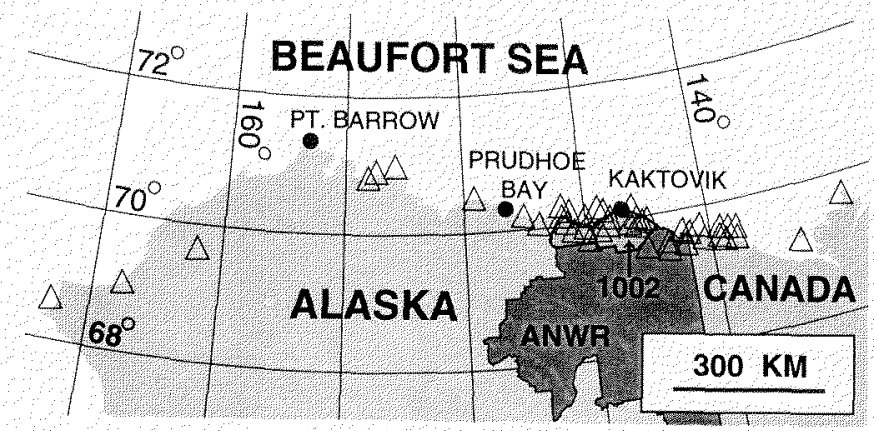

FIG. 1. Locations of dens found by radiotelemetry along the Alaskan and Canadian mainland coasts between 1981 and 1992 (modified by Amstrup and Gardner, 1994: Fig. 2). Of the dens located, 45 and $34 \%$ were on ANWR and the 1002 area. Also shown are place names used in the text.

\section{Potential Disturbances at Dens}

Litters of 38 radiocollared bears (including numbers 3,4 , 9 , and 11 below), 28 marked bears, and 52 new bears were captured after emergence from maternity dens in the spring (Table 1). Four denned bears were exposed to more intense than usual aircraft activity associated with this study, and 8 were exposed to activities of persons engaged in other endeavors (Table 2).

Responses to Aircraft: We recorded 40 cases (including bears 1-4 below) of potential disruptions of denning by research aircraft. Motions detectable among collared bears within dens did not appear to be elevated during telemetry flights, and only bears 1 and 3 left their dens. Production of cubs (Table 1) by radiocollared, marked, and new bears did not differ $\left(\chi^{2}=1.31, \mathrm{df}=2, \mathrm{P}=0.519\right)$. Likewise, skull measurements $\left(K W, \chi^{2}=4.1, \mathrm{df}=2, \mathrm{P}=0.13\right)$ and body weights $\left(K W, \chi^{2}=2.79,2 \mathrm{df}, \mathrm{P}=0.25\right)$ of cubs born to females in each group did not differ.

Responses of 4 denned bears exposed to greater than usual levels of aircraft disturbance during this study were mixed. Bear 1 was seen digging her den in a deep snow bank when the helicopter flew over her, on 30 October 1984, at an altitude of approximately $100 \mathrm{~m}$. She fled but was captured, instrumented, and released adjacent to her excavation. After recovery, bear 1 wandered extensively until 2 December, when she was relocated in another den $64 \mathrm{~km}$ west of her capture.

Bear 2 was observed in her open den on 19 October 1981. She came to the entrance when the helicopter hovered $300 \mathrm{~m}$ in front of and $100 \mathrm{~m}$ over her den. Bear 2 was observed in the entrance of her den three more times before 28 October, when blowing snow closed the den for the winter. Those sightings included a slow, $50 \mathrm{~m}$ high, overhead flight that occurred by accident on 26 October. Because bear 2 was an unmarked bear, her presence through the winter was not verified. However, a female with 2 cubs was observed by a local resident at the den site on 22 March 1982.

Bear 3 ran from her open den on 5 November 1983 (the third day she had been seen there) when the helicopter hovered $100 \mathrm{~m}$ overhead and $100 \mathrm{~m}$ in front of her den. She was caught and released adjacent to her den but traveled as far away as $120 \mathrm{~km}$ before entering a second den $20 \mathrm{~km}$ from her first. Bear 3 was monitored by radiotelemetry through the winter and emerged from her den in the spring with 2 cubs.

The closed den of bear 4 was first located on 19 March 1991 by several $200 \mathrm{~m}$ high overhead flights with a twin engine turboprop aircraft. The transmitter signal indicated no detectable activity of the bear in the den during these flights. On 27 March no signal was heard, despite numerous passes at 30-50 m altitudes. I assumed bear 4 had left her den but learned later the radio receiver had malfunctioned. On 5 April the den was open and polar bear footprints led from the den to a point $100 \mathrm{~m}$ to the south and then returned to the den. On 7 April, more footprints leading away from and back to the den were observed. Also, snow machine tracks circled the polar bear footprints and approached to within $10 \mathrm{~m}$ of the den exit. Bear 4 left the den on 13 April 1991 
TABLE 1. Litter sizes, skull measurements, and weights of cubs captured with female polar bears after emerging from maternity dens in the spring (differences among classes of females were not significant)

\begin{tabular}{|c|c|c|c|c|c|c|c|c|c|}
\hline \multirow[b]{2}{*}{ Female class ${ }^{2}$} & \multicolumn{3}{|c|}{ Litter size } & \multicolumn{3}{|c|}{ Skull sizes ${ }^{1}(\mathrm{~cm})$} & \multicolumn{3}{|c|}{ Weight (kg) } \\
\hline & $\mathbf{N}$ & Mean & St. dev. & $\mathbf{N}$ & Mean & St. dev. & $\mathbf{N}$ & Mean & St. dev. \\
\hline New & 52 & 1.65 & 0.48 & 19 & 26.43 & 2.07 & 23 & 29.48 & 6.65 \\
\hline Marked & 28 & 1.53 & 0.51 & 23 & 27.43 & 1.87 & 18 & 35.78 & 11.29 \\
\hline$\underline{\text { Radiocollared }}$ & 38 & 1.66 & 0.48 & 36 & 27.41 & 1.87 & 34 & 30.59 & 9.95 \\
\hline
\end{tabular}

${ }^{1}$ Skull measurements shown are the sum of condylobasal length and zygomatic width.

2"New" females had never been captured before; "Marked" females were captured and marked or radiocollared prior to entering their dens, but were not located in dens by aircraft radiotelemetry; "Radiocollared" females were captured and radiocollared prior to denning and located in their dens by low-altitude aircraft radiotelemetry.

TABLE 2. Summary of observations of polar bears exposed to human activities while in dens (numbers of cubs observed upon emergence and subsequent survival of those cubs are shown)

\begin{tabular}{|c|c|c|c|c|c|c|}
\hline Bear no. & Possible perturbation & Time of disturbance & Distance to disturbance & Behavioral response & No. cubs & Minimum survival \\
\hline 1 & Aircraft, capture & $30 \mathrm{Oct}$ & $100 \mathrm{~m}$ & Redenned & $\mathrm{N} / \mathrm{A}$ & N/A \\
\hline 1 & Rollagon train & Early Jan & $250 \mathrm{~m}$ & Left den? & 0 & N/A \\
\hline 2 & Aircraft overflight & 19 Oct & $<50 \mathrm{~m}$ & None & 2 & Unknown \\
\hline 3 & Aircraft, capture & 5 Nov & $100 \mathrm{~m}$ & Redenned & 2 & Weaned \\
\hline 4 & Aircraft, snow machine & Mar-Apr & $<50 \mathrm{~m}$ & None & 1 & $<6$ months \\
\hline 5 & Aircraft, foot traffic & 8-11 Mar & $<50 \mathrm{~m}$ & Left \& returned & 1 & Unknown \\
\hline 6 & Snow machine & Late Mar & $\sim 200 \mathrm{~m}$ & Left den? & 0 & $\mathrm{~N} / \mathrm{A}$ \\
\hline 7 & Oil field operations & Continuous & $2.8 \mathrm{~km}$ & None & 2 & Unknown \\
\hline 8 & Oil field operations & Continuous & $2.8 \mathrm{~km}$ & None & 2 & $>6$ months \\
\hline 9 & Seismic survey & Jan-Apr & $1000 \mathrm{~m}$ & None & 2 & $<6$ months \\
\hline 10 & Seismic survey & Jan-Apr & $2 \mathrm{~km}$ & None & 2 & $>1$ month \\
\hline 11 & Oil field operations & Dec-Apr & $\sim 400 \mathrm{~m}$ & None & 2 & $>1$ month \\
\hline 12 & Field survey & 9-19 Mar & $46 \mathrm{~m}$ & None & 2 & Unknown \\
\hline
\end{tabular}

and was recaptured with a single cub $5 \mathrm{~km}$ north of the den. Bear 4 remained in her den despite numerous exposures to low-level aircraft and the close approach of a snow machine and emerged later, presumably without human influence.

Unmarked bear 5 was exposed to humans on foot as well as aircraft. On 8 March 1981, B.P. Kelly observed a den opening on a northshore barrier island. On approaching the den (by helicopter) to investigate, bear 5 and a single cub emerged and fled north onto the sea ice. The helicopter landed at the den site. Kelly entered the den, recorded some notes regarding its structure, made a sketch, and departed. On 11 March 1981, Kelly returned to the den site by helicopter, landed, and walked to the den to make more notes, but bear 5 was back. Bear 5 and cub were observed, by helicopter, to occupy the den area until 13 March. Kelly did not visit the den thereafter.

Exposure to Over-Snow Vehicles and Activities: The sealed den of bear 6 was radio located on a Canadian northshore island on 12 January and 9 March 1984. She left the den shortly thereafter, however, and was next observed without cubs in June 1984. A local hunter later reported seeing a running polar bear in late March near the draw where the den of bear 6 was located. The hunter thought the bear had just come from a den, but he did not investigate whether cubs may have been left behind. The bear he observed might have been number 6 , and it is possible that the passing of his snow machine induced her to abandon her den.

Two maternity dens (bears 7 and 8) were found on the south shore of a barrier island in spring 1991 within $2.8 \mathrm{~km}$ of an oil production plant employing $80-90$ people. Vehicle traffic, human activity, and associated noises were constant throughout the denning period. Bear 8 was followed from her den, captured, and radiocollared. Her 2 cubs were known to survive at least 6 months thereafter. Tracks of 2 cubs emerged from the den of bear 7, but their survival after leaving the den was not known.

Bear 1, which had been disturbed by helicopter at her first den site in fall 1984, may have been disturbed from the site to which she relocated. She was in her second den on 2 and 27 December 1984, but on 11 February 1985 she was alone on the sea ice near Barrow. Examination of her den location revealed a single Rollagon tractor (Crowley All-Terrain Corp., Anchorage, AK) path within $250 \mathrm{~m}$ of the den site and a well-traveled Rollagon path parallel to the coast at a distance of 450-500 m from the den site. Rollagon tractors weigh approximately $27000 \mathrm{~kg}$, and trailers weigh between 17000 and $20000 \mathrm{~kg}$. Both tractors and trailers ride on tall, wide, low-pressure tires, and ground impact is $0.30 \mathrm{~kg} / \mathrm{cm}^{2}$ (4.2 psi).

Two denning animals were exposed to three-dimensional seismic exploration (Yilmaz, 1987) and Rollagon traffic during the winter of 1988-89. A satellite radiocollared bear (number 9) denned on a northcoast barrier island on 20 October 1988, and an unmarked bear (number 10) was observed in a den just east of the den of bear 9 on 1 November 1988. The eastern-most receiver line of the seismic grid was $1000 \mathrm{~m}$ west of the den of bear 9 and $2000 \mathrm{~m}$ west of the den of bear 10 . The parallel seismic lines were approximately $10 \mathrm{~km}$ long, spaced at intervals of $50 \mathrm{~m}$, and extended $27 \mathrm{~km}$ east to west. The Rollagon traffic approached to within 
$2500 \mathrm{~m}$ and $3400 \mathrm{~m}$ of the dens of bears 10 and 9 respectively.

Bear 9 and her 2 cubs remained in their sealed den as the Rollagon units passed and during the time the seismic crews were nearest $(1000 \mathrm{~m})$. Temperature and activity data relayed from the satellite radiocollar of bear 9 suggested she opened her den between 8 and 11 February, when seismic testing was done on source lines 1900-2500 m west of her den, and left her den on 12 March, when activity occurred $6300 \mathrm{~m}$ west of her. Bear 9 was captured with 2 cubs of the year on 9 April 1989, 29 days after leaving the den. Footprints of a female and 2 cubs at the den of bear 10 on 1 April may be evidence that she left the den with cubs, but her success was not substantiated by subsequent observations.

A heavily used ice road passed $400 \mathrm{~m}$ in front of the den of bear 11 when her open den was located on 22 March 1992. Footprints around the den exit indicated bear 11 and cubs had been in and out of the den several times by 22 March. Road construction started 22 December 1991 and was concluded 28 January 1992 . Drilling $6 \mathrm{~km}$ down the road from the den began on 7 February and was completed in April. At least six light vehicles and one large truck passed in front of the den every other day, and at least four runs each day were made by both a blade-type snowplow and a rotary snowblower. Traffic was heavier during and after snow or wind storms and during construction. The mean den entry date recorded for the Beaufort Sea area was 18 November, and all bears that produced cubs entered dens on land before 24 November (Amstrup and Gardner, 1994). Therefore, bear 11 must have been in her den when construction work began. Workers on the road and drilling project were unaware of the presence of the bear, and the bear apparently tolerated the relative nearness of the construction activities and traffic. On 25 March, bear 11 took her 2 cubs north across the ice road and onto the sea ice.

Unmarked bear 12 emerged from and reentered her open den as a survey party traveling in a $7000 \mathrm{~kg}$ tracked vehicle and two light snow machines approached to within $65 \mathrm{~m}$ on the morning of 19 March 1993 . The survey party, which was staking seismic shot lines, withdrew and ceased operations. Subsequent observations from a $400-500 \mathrm{~m}$ high Cessna 185 aircraft and a knoll $680 \mathrm{~m}$ from the den verified that bear 12 and her 2 cubs used the area around the den and the den itself until the morning of 21 March, when they walked north to the sea ice. Records verified that the same survey crew passed within $46 \mathrm{~m}$ of the den, which was closed then, on 9 March 1993. They also surveyed the lines $270 \mathrm{~m}$ and $135 \mathrm{~m}$ from the den on 13 and 18 March respectively. Thus, bear 12 tolerated several close approaches to her den and left later, in the absence of human activity.

\section{DISCUSSION}

Polar bears denned on ANWR and the 1002 area more frequently than would have been expected if they denned uniformly along the mainland coast. Amstrup and Gardner (1994) documented that the preponderance of dens in the northeastern coastal area of Alaska represented a statistically significant preference. The potential for disruption of dens in that area, therefore, must be taken seriously.
On the other hand, most bears in this study showed substantial tolerance for human activities. Pinpointing the locations of the dens of radiocollared polar bears by aircraft required more overhead flights at lower altitudes than most other kinds of aircraft travel. Also, live capture and marking were probably more disruptive to bears than other possible perturbations. Yet, recruitment of cubs through the time of emergence from the den and sizes of cubs were not affected by those disruptions. Ramsay and Stirling (1986) reported that capturing and handling female polar bears in Canada did not significantly affect numbers or sizes of cubs.

Interactions of denned polar bears and industrial activities have not been reported elsewhere. However, observations of grizzly bears (Ursus arctos), which are closely related to polar bears, also suggested substantial tolerance of such activities. McLellan and Shackleton (1989) found that summer active grizzly bears were not displaced from the immediate vicinity of seismic testing supported by helicopters. Reynolds et al. (1986) reported some movements and possible increased heart rates when denned grizzly bears were exposed to seismic testing activities. However, they also observed that similar movements and heart rate patterns sometimes occurred in absence of human activities, and they concluded that "effects on the bears were probably minimal" (Reynolds et al., 1986:174).

After studying sounds and vibrations detectable in artificial dens, Blix and Lentfer (1992) observed that only seismic testing less than $100 \mathrm{~m}$ from a den and a helicopter taking off at a distance of $3 \mathrm{~m}$ produced noises inside the dens that were notably above background levels. Blix and Lentfer (1992) also concluded that a polar bear in its den is unlikely to feel vibrations unless the source is very close. They did not address, however, the formation of ice and the increasing density of snow that occurs when a den is occupied all winter and which would reduce insulation quality of the snow. Nor did they address the great individual variation in behaviors of polar bears.

Many questions about how bears in "real dens" are affected by disturbances remain unanswered. Bears 2, 4, 5, and 7-12 tolerated various activities near their dens, and bears exposed to research-related disturbances were not negatively affected. These observations corroborated the conclusion of Blix and Lentfer (1992) that bears in dens are well insulated from outside sounds and vibrations. The possible den abandonment by bears 1 and 6 may be evidence to the contrary. However, during this study, 22 radiocollared bears not exposed to human disturbances abandoned their dens without cubs. Thus, although I cannot rule out a cause-and-effect relationship, it is equally likely the departures of bears 1 and 6 were unrelated to human activities. Kelly et al. (1988) demonstrated that efforts generating large sample sizes that lend themselves to hypothesis testing can quantify effects of industrial disturbances. Unequivocal conclusions regarding sensitivities of denned polar bears to industrial disturbances will be available only from similar controlled studies.

Polar bears may be more willing to abandon dens in fall than later in the denning period. Belikov (1976) reported that polar bears were easily disturbed from their dens in the fall, and I observed 2 bears (numbers 1 and 3 ) abandon their 
fall dens in response to disturbances that appeared less severe than those tolerated by some bears in the spring. Also, evidence for the two cases (bears 1 and 6) of possible human-induced abandonment of dens in spring was only circumstantial.

Bears have less to lose by leaving a den in the fall than they do by leaving nearer the time of parturition or afterward. Amstrup and Gardner (1994) confirmed that the survival of cubs prematurely forced out of their dens by movements of the sea ice was poor. They also concluded that individual polar bears have strong ties to general areas and substrata, but not to particular denning sites, and that most bears enter dens in November. It is less expensive for a bear looking for a den site to find an alternate location than it is to abandon an occupied den and create another elsewhere. Therefore, initiation of intense human activities in October or November would give bears en route to land dens the opportunity to den in less disturbed areas. Also, bears already in dens could relocate more easily when parental investment is low. The 2 bears I captured at dens in the fall reentered dens at other locations, and 3 bears disturbed from dens near Hudson Bay in autumn also relocated to other den sites (Ramsay and Stirling, 1986).

\section{CONCLUSIONS}

Polar bears preferred to den on and near ANWR, and if hydrocarbon development occurs there, the potential for disturbance of denning polar bears will increase. Loss of a large portion of the present productivity of polar bears denning on ANWR would undermine recruitment in the Beaufort Sea population. However, data indicate that many denned bears exposed to human activities are likely not to be affected in ways that alter their productivity. Also, rigorous adherence to flexible management strategies, including spatial and temporal restrictions of developments, could prevent the potential for many disruptions of dens from being realized.

\section{ACKNOWLEDGEMENTS}

Principal funding for this work was provided by the U.S. Fish and Wildlife Service, U.S. Department of Interior. The Minerals Management Service, U.S. Department of Interior; the National Oceanic and Atmospheric Administration, U.S. Department of Commerce; AMOCO Inc.; ARCO Alaska, Inc.; BP Exploration Alaska, Inc.; Dome Petroleum Ltd.; Beaudrill/Gulf Canada Ltd.; and the Northern Oil and Gas Assessment Program (NOGAP) of Canada (in cooperation with the Departments of Renewable Resources of the Northwest Territories and the Yukon Territory) also contributed. I thank D. Andriashek, G.W. Garner, J. Gravning, E. Henderson, B. Smith, F. Sorensen, and I. Stirling for assistance and advice in the field, office, and laboratory. R.T. Bowyer, F.C. Dean, F.H. Fay, E.H. Follmann, D.R. Klein, and S.D. Miller provided helpful comments on this manuscript. Use of corporate names, brand names, and trade marks does not constitute endorsement by the Government of the United States.

\section{REFERENCES}

AMSTRUP, S.C., and GARDNER, C. 1994. Polar bear maternity denning in the Beaufort Sea. Journal of Wildlife Management 58(1). In press.

AMSTRUP, S.C., STIRLING, I., and LENTFER, J.W. 1986. Past and present status of polar bears in Alaska. Wildlife Society Bulletin 14:241-254.

BELIKOV, S.E. 1976. Behavioral aspects of the polar bear, Ursus maritimus. International Conference on Bear Research and Management 3:37-40.

BLIX, A.S., and LENTFER, J.W, 1992. Noise and vibration levels in artificial polar bear dens as related to selected petroleum exploration and developmental activities. Arctic 45:20-24.

CLOUGH, N.K., PATTON, P.C., and CHRISTIANSEN, A.C., eds. 1987. Arctic National Wildlife Refuge, Alaska, coastal plain resource assessment - Report and recommendation to the Congress of the United States and final legislative environmental impact statement. Washington, D.C.: U.S. Department of the Interior (U.S. Fish and Wildlife Service, U.S. Geological Survey, U.S. Bureau of Land Management). 2 vols. $1306 \mathrm{p}$.

CONOVER, W.J. 1980. Practical nonparametric statistics. 2nd ed. New York: John Wiley and Sons, Inc. 493 p.

HARINGTON, C.R. 1968. Denning habits of the polar bear (Ursus maritimus). Canadian Wildlife Service Report Series 5. $33 \mathrm{p}$.

KELLY, B.P., BURNS, J.J., and QUAKENBUSH, L.T. 1988. Responses of ringed seals (Phoca hispida) to noise disturbance. In: Sackenger, W.M., Jeffries, M.O., and Imm, J.L., eds. Port and ocean engineering under arctic conditions. Fairbanks: Geophysical Institute, University of Alaska, Fairbanks. 27-38.

KOSTYAN, E.Y. 1954. New data on the reproduction of polar bears. Zoological Journal 33:207-215. Translated from Russian.

LENTFER, J.W., and HENSEL, R.J. 1980. Alaskan polar bear denning. International Conference on Bear Research and Management 4:101-108.

McLELLAN, B.N., and SHACKLETON, D.M. 1989. Grizzly bears and resource extraction industries: Habitat displacement in response to seismic exploration, timber harvesting and road maintenance. Journal of Applied Ecology 26:371-380.

RAMSAY, M.A., and DUNBRACK, R.I. 1986. Physiological constraints on life history phenomena: The example of small bear cubs at birth. American Naturalist 127:735-743.

RAMSAY, M.A., and STIRLING, I. 1986. Long-term effects of drugging and handling free-ranging polar bears. Journal of Wildlife Management 50:619-626.

RAMSAY, M.A., and STIRLING, I. 1990 . Fidelity of female polar bears to winter-den sites. Journal of Mammalogy 7:233-236.

REYNOLDS, P.E., REYNOLDS, H.V., and FOLLMANN, E.H. 1986. Responses of grizzly bears to seismic surveys in northern Alaska. International Conference on Bear Research and Management 6:169-175.

YILMAZ, Ô. 1987. Seismic data processing. Tulsa, OK: Society of Exploration Geophysicists. 526 p. 